\title{
Study on Strategy of Construction of Rural Culture with Assistance of University Library in the View of Rural Revitalization Strategy
}

\author{
Lina Li \\ Library and Information Center, Heilongjiang Bayi Agricultural University, Daqing, China \\ Email: byndcscy@126.com
}

How to cite this paper: Li, L.N. (2018) Study on Strategy of Construction of Rural Culture with Assistance of University Library in the View of Rural Revitalization Strategy. American Journal of Industrial and Business Management, 8, 2191-2199. https://doi.org/10.4236/ajibm.2018.811146

Received: September 27, 2018 Accepted: November 19, 2018 Published: November 22, 2018

Copyright $\odot 2018$ by author and Scientific Research Publishing Inc. This work is licensed under the Creative Commons Attribution International License (CC BY 4.0).

http://creativecommons.org/licenses/by/4.0/

\begin{abstract}
The report of the 19th National Congress of the Communist Party of China proposed to implement the strategy of rural revitalization. The rural culture construction is the soul of the strategy of rural revitalization. In the overall environment of comprehensive and sustainable development of our society, the university libraries play an important role in serving local areas. This paper summarizes the current situation and existing problems of rural cultural construction in Daqing and puts forward solutions and specific countermeasures for promotion of rural cultural construction by the university libraries in Daqing. This discuss enriched the study of cultural construction within the scope of small administrative regions in China and related contents of cultural reconstruction in Rural Revitalization Strategy.
\end{abstract}

\section{Keywords}

Rural Revitalization Strategy, University Library, Rural Culture Construction

\section{Introduction}

President Xi stressed, "Culture is the soul of a country and a nation. The prosperity and power of the country depend on the strong and diverse culture. There would be no great rejuvenation of China without strong confidence and prosperity of culture. "The 'Opinions of the CPC Central Committee and the State Council on the Implementation of Rural Revitalization Strategy' issued by the CPC Central Committee and the State Council issued on January 2, $2018 \mathrm{em}$ phasized to" boom the rural culture and glow the new atmosphere of rural civilization" [1]. In recent years, with the rapid development of economy and the continuous improvement of policies, the material living standard of farmers has been continuously improved, their demand for spiritual culture has grown ra- 
pidly, and thus meeting their increasing demand is the basis for promoting the construction of rural culture.

Since 2004, China Society for Library Science has conducted the selection of "Advanced Unit of National Reading Activities" and "National Reading Demonstration Base" every year in China. As of April 2018, a total of 42 university libraries have won the award. University libraries are playing an increasingly important role in reading promotion in China. As the literature information center of university and the forward position of cultural communication, these libraries have advantages in information technology talents, information technology equipment and information resources gathering. With serving the teaching and scientific research of the university, it also can offer service to the construction of local culture. As an important part of the public cultural service system, university libraries have the responsibility and obligation to promote the construction of local culture through their own efforts [2]. In particular, the libraries of agricultural colleges and universities should develop their own advantages for the construction of local rural culture.

At present, Daqing's rural cultural construction has developed rapidly, cultural activities and service groups are also increasing, the cultural quality of farmers has improved, cultural life is growing, the level of cultural consumption has raised, public cultural infrastructure has gradually improved, awareness of traditional cultural protection has obviously strengthened, and rural ecological environment has been developed. All 58 villages and towns in the city build their own comprehensive cultural station (with an area of more than 300 square meters for each station), 242 community comprehensive cultural activity centers, 210 village comprehensive cultural service centers, 279 cultural and sports squares and 49 central village cultural squares. And such people-benefit projects as the rural libraries, rural film showing, radio and TV village project have fully covered. In 2017, there were 6 public libraries in the city, with a total of 2.566 million books and of 1 million readers. And there were also 485 village libraries. The cultural infrastructure is complete, the spirit of cultural team is in good condition and the cultural activities at the grass-roots level are rich and colorful since the city has invested heavily in cultural construction.

In order to further grasp the actual situation of rural cultural construction in Daqing, the author checked the relevant materials of local cultural construction through the official website of local governments, collected relevant data and visited 12 towns and 47 villages in the Datong district, Duerbote Mongolia Autonomous County, Lindian County and Zhaozhou County to deeply investigate the basic situation of rural cultural construction and summarize the existing weaknesses in the construction.

\section{Weaknesses in the Construction of Rural Culture in Daqing}

\subsection{Inadequate Construction of Cultural Infrastructure}

The township cultural stations in Daqing are facing with following poor condi- 
tions, such as old and aging equipment and facilities and incomplete internal functions. The village-level cultural activity room does not have enough construction area, and most of them are in the mode of comprehensive utilization and resource sharing. Some districts and counties are lack of indoor sports halls and fitness paths, and individual squares do not have the paths even. The mass have a higher and higher demand for the cultural service products, the quality of theatrical performances, the types of books and publications and the cultural service equipment such as piano and sound, so insufficient supply becomes the highlighted problem in the culture services.

\subsection{Low Utilization of Cultural Infrastructure}

The cultural infrastructures in Daqing are not utilized efficiently. Through communication with villagers, we found that only the basic fitness facilities are often used for most of people, such as cultural square and fitness equipment. A series of public cultural infrastructure are now built in rural areas according to the requirements of the superior governments. The number of public cultural infrastructure can reach the standard, but some public cultural service facilities are in name only and not really used, resulting in a waste. The free opening hours of libraries, cultural centers and cultural stations in some counties and districts do not meet the people's requirement.

\subsection{Incomplete Cultural Guarantee System}

At the grass-roots level, the people always emphasize economy over culture and believe that the construction of the public cultural service system and the allocation, management and utilization of resources are the "supporting roles" in the work, resulting in the lack of matching funds and the unsustainable construction of major culture projects. The grass-roots government thinks that economic construction will give the timely help to the local and the cultural construction is the icing on the cake only. In all kinds of appraisals, economic construction accounts for a large proportion. There is less investment in capital and manpower for cultural construction and it is impossible to carry out various cultural activities well, leading to a vicious circle.

\subsection{Weak Construction of Cultural Team}

In Daqing, the rural cultural team is difficult to enter every village because most of the workers are in part-time job and only a few of them are in full-time due to the staffing problem and the team is basically directly under the management of villages and towns, with low work enthusiasm and lack of professional business training. The elderly in the cultural team is in the majority, who lack the advanced culture and technology but is at a low theoretical level, and thus the cultural talents is short of reserve forces and the cultural development does not have enough vitality, as a result, this team cannot play a role in carrying out mass cultural activities and guiding grass-roots work. Furthermore, the head of 
rural cultural station cannot offer efficient service due to non-professional, aging and not loving. The rural library has some shortages in management as its administrator is part-time worker and has low level of education.

\subsection{Insufficient Innovation of Cultural Activities}

During the construction of rural culture in Daqing city, some brand activities have emerged, and each district and county also organize relevant events according to local conditions, but the participation of farmers is not high, the range of target audience is not large, and its influence to the surrounding areas are not enough. At present, the most popular cultural activities are square dancing and film showing, while the more elegant cultural activities such as painting and calligraphy exhibition, photography exhibition and concert are very rare. Currently, most of the popular activities are characterized by low-level imitation, lack of individual characteristics and of innovation. The traditional folk culture activities also have some problems, such as too single form and content and lack of application of advanced science and technology.

\subsection{Primitive Public Culture Informatization}

In many rural areas, information construction is very primitive due to information blockage and insufficient resources, resulting in a deviation in the understanding of cultural construction between grass-roots government and villagers, as well as the low utilization rate of public cultural resources. With the rapid development of new media technology, the official WeChat platform has become the first choice for all kinds of cultural propaganda, but the WeChat service offered by grassroots cultural institutions in Daqing is relatively poor. Meanwhile, there are a few of digital resources of county libraries and cultural centers and it is difficult to share these with city centers, so that the digital resources available to villagers are small in quantity and their types are not rich and cannot be updated timely.

\subsection{Insufficient Inheritance and Development of Excellent Traditional Culture in Rural Areas}

Nowadays, the historical and cultural relics in Daqing's rural areas are seriously damaged, so the relevant departments should take actions to master the first-hand information of cultural relics, protect and restore the historical and cultural relics as far as possible and use the relics to carry out cultural activities and give full play to their value. The outstanding rural folk art and minority culture in every district and county of Daqing need to be deeply excavated, so we can learn from the inheritance and development model of the projects in other areas, such as "Yangxiaoban drum music tent" in Zhaozhou county and "Shaman folk paper cutting" in Lindian county.

\subsection{Low Enthusiasm to Participate}

In winter, the villagers are used to gather together to drink or play cards due to 
the severe cold and heavy snow, as well as lack of indoor cultural places. In summer, few people like to take part in cultural activities because of the long sun exposure and high temperature outside. In the spring and autumn, the farmers are busy in farm work and are obviously not motivated to participate in such activities. In addition. Moreover, most villagers are willing to participating in welfare cultural activities at no cost. And they would like to participate if the props need to be purchased at their own expense.

\subsection{Outdated Cultural Customs}

Farmers' demand for culture shows obvious differences in age and gender. Most of the old women like watching TV, playing mahjong and performing square dances and are less interested in some elegant cultural activities and rarely organize the activities spontaneously. The emptiness of villagers' spiritual culture leads to excessive attention to the material basis, and some villagers pay much attention to increases in their income, which causes the money worship and hedonism to prevail in a certain range. Besides, feudal superstition and backward traditional customs still exist. Some farmers believe in ghosts and gods and not in Marxism-Leninism, so the fortune telling is common and popular.

\section{Basic Way to Build Rural Culture in Daqing}

\subsection{Strengthen the Implementation of Various Policies}

Establish and improve the financial guarantee mechanism for public cultural services, ensure that the growth rate of public financial investment in cultural construction is higher than the growth rate of regular financial revenue, and raise the proportion of cultural expenditure to financial expenditure. Strengthen the implementation of policies to support public cultural services in such areas as project acquisition, financial subsidies, tax incentives, financial support, land planning and market access. Cultural departments at all levels should step up publicity and implementation of various policies, further implement various cultural policies issued by higher levels, ensure the actual needs of cultural work (township cultural stations and community activity centers) in terms of funds and staffing, and comprehensively promote the sustained and healthy development of cultural work [3].

\subsection{Strengthen the Construction of Public Cultural Infrastructure}

Accelerate the full coverage of community and township comprehensive cultural stations (farm library, cultural yard) as well as the village cultural squares, and increase investment in community fitness \& leisure squares and village activity squares. Vigorously promote the construction of key public cultural facilities at the county level, and carry out the construction and upgrading of comprehensive cultural stations and cultural activity rooms in villages, towns and communities. Strengthen the standardized management of comprehensive cultural stations in villages and towns, continuously improve the service quality, and ensure 
that all administrative villages in the county have cultural activity centers with an area of not less than $100 \mathrm{~m}^{2}$, and communities have the centers with an area of not less than $300 \mathrm{~m}^{2}$.

\subsection{Strengthen the Construction of Public Cultural Talent Team}

Further improve the talent selection and employment mechanism, and strive to cultivate a group of public cultural managers and grassroots service personnel with modern and innovative consciousness. Improve the system and mechanism of personnel training and use, strengthen the training of cultural service personnel, and continuously raise the quality and ability of these service personnel. Effectively improve the salary and benefit of cultural workers at the grass-roots level, stabilize cultural teams by staffing policy and cultivate the cultural backbones. Establish and improve the talent pool for folk literature and art and the training mechanism for cultural talents team. Attract all kinds of talents to enter the field of public cultural services and encourage college graduates to work in public cultural services at the grass-roots level. Vigorously develop the team of cultural volunteers, establish the selection, training and incentive mechanism for the volunteers, and encourage and guide the college students and high-quality retirees to participate in public cultural services [4].

\subsection{Increase Investment in the Construction of Public Cultural Service System}

The first is to increase the investment of special funds in rural cultural construction, focusing on the construction of public cultural facilities. The second is to continuously open public cultural facilities free of charge and ensure to open all public libraries and cultural centers (stations) at no cost. The third is to support the development of major cultural activities in rural areas and increase investment in rural cultural activities such as farmers' songs and performances by folk art groups [5].

\subsection{Strengthen the Information Construction of Public Culture}

First, the digital platform should be available to villagers. Cultural sites at all levels should set up their own official websites and WeChat platforms for promotion of various resources and information and can also use new media means such as WeChat Group, QQ Group, Micro Blog and WeChat to publish various messages, notices and micro-cultures. Second, improve the digital equipment in public cultural places, such as Bookan touch screen, Bookan micro-bookstore, Bookan reading booth and Goethe digital book machine and other electronic reading equipment. The last is to complete the coverage of the wireless network in cultural activity sites for provision of digital services.

\subsection{Strengthen the Ideological and Moral Construction in Rural Areas}

The first is to adopt an effective way conforming to the characteristics of the 
countryside under the guidance of socialist core values, deepen the publicity and education of socialism with Chinese characteristics and the Chinese dream, and vigorously promote the national spirit and the spirit of the times. The second is to strengthen the education of patriotism, collectivism and socialism, deepen the education of national unity and progress, and enhance the construction of ideology and culture in rural areas. The third is to carry out moral construction projects, dig traditionally moral education resources in rural areas and promote the construction of social morality, family virtue and personal morality. The fourth is to promote the construction of good faith and strengthen villagers' awareness of social responsibility, rules and ownership.

\subsection{Strengthen the Inheritance and Development of Excellent Rural Culture}

The first is to strengthen the excavation and protection of cultural relics, increase the scope and intensity of collection of folk relics, hold special cultural exhibitions and develop the museum undertaking. The second is to support the development of traditional culture with rural characteristics, make the protection projects enter the schools, communities and villages, and expand the influence and number of protection projects [6].

\subsection{Establish and Improve the Performance Evaluation System of Rural Cultural Construction}

Include the construction of public culture in the important agenda of villages and towns (communities) and relevant departments, in the integrated target assessment, in the budget at the same level, and incorporate the facilities construction into the overall planning of urban and rural construction. Incorporate the achievements of public cultural construction into the comprehensive evaluation system for local economic and social development and into the performance evaluation system for leaders at all levels.

\section{Specific Solutions for Promotion of the Construction of Rural Culture in the University Library in Daqing}

\subsection{Enriching Rural Cultural Infrastructure Relying on Resource Advantages}

There are 6 universities in Daqing, and their libraries are advanced in management and rich in resources. And the library in Daqing can negotiate with the university and collect some books with more copies which are stored in the warehouse and easy for farmers to understand to present to rural library as the gift. The books donated by graduates to the library during the graduation can be selected and donated to the grass-roots rural library. For example, the library of Heilongjiang Bayi Agricultural University presented 100 books to the Daxing Township Government in Zhaoyuan County as the gift in 2013. In October 2017, it launched a "Book Exchange Campaign" and selected more than 300 books to distribute to four 2018 summer teaching teams, and the members of the 
team took these books to the cultural institutions where they worked. Libraries have purchased a certain amount of digital reading equipment and databases, which can share some digital resources with rural cultural institutions. The university library in Daqing should give full play to the professional advantages of each school, further enrich the types and quantity of donated books and make full use of book resources while satisfying the use of teachers and students in the university, so as to enrich rural cultural life, improve the humanistic quality of farmers, effectively bring the social benefits of the university library into play and lay a solid foundation for the construction of rural culture.

\subsection{Improving the Quality of Rural Cultural Team Relying on the Advantages of Talents}

Teachers with high academic degrees are the greatest talent advantage available to the university libraries, compared with other libraries. Apart from their rich professional knowledge, these teachers with high-level education also have good foreign language skills and computer application ability, therefore, they play an important role in these fields, such as library resource construction, information analysis, consulting services, characteristic database establishment, network maintenance, software development, etc. College teachers can engage into the construction of rural culture in the form of part-time jobs and long-distance tutoring. College students are talented, enthusiastic, thoughtful and innovative, so we can introduce the students from various universities into the rural cultural team. The rich and colorful cultural activities in colleges and universities can be presented to the grassroots farmers through the poverty alleviation and live internet broadcast.

\subsection{Speed up the Construction of Rural Cultural Informatization Relying on Technical Advantages}

With the rapid development of big data and new media, the WeChat platform has been rapidly used by university libraries in a short time with respect to the popularity of new media represented by WeChat. In October 2013, the library of Heilongjiang Bayi Agricultural University opened WeChat service and directly linked to digital resources such as Super Star Mobile Library, Bookan Audio, Bookan Micro-magazine and so on. Farmers can use the open resources and read past events by following the official accounts. Bayi Agricultural University has made great progress in the construction of smart campus and network security. The grass-roots cultural departments in various districts and counties can make use of and draw lessons from existing technologies, and also request technical support from university libraries in the process of informatization construction of their subordinate units.

\subsection{Enriching the Types of Rural Cultural Activities Relying on the Advanced Ideas}

The university library is playing a more and more important role in promotion 
of nationwide reading work. Under the guidance of advanced reading promotion ideas, the university library has implemented some reading activities that are simple to operate, low in activity funds and willing to participate by readers. Rural cultural organizations can learn from the development of reading promotion activities in university libraries and enrich reading activities at the grass-roots level in rural areas. For example, such activities as Shuying reading, real person library, reading salon, Wang Zhen's lecture hall, classic literature contest, reading cosplay, reading partner, 21-day reading, reading aid contest, teachers and students booking sharing event, etc. carried out by Heilongjiang Bayi Agricultural University are in a novel form and easy to operate, so that the farmers can directly participate in by following the Wechat account.

\section{Funding}

This paper is a research projects of Heilongjiang Provincial Department of Culture Provincial Art Planning Project "Research on Cultural Construction in Rural Revitalization Strategy" (Project Number: 2018D024); Daqing Philosophy and Social Science Planning "Study on the Strategy of University Library to Promote the Construction of New Rural Culture in Daqing under the Background of Big Data" (Project Number: DSGB2018129); Heilongjiang Bayi Agricultural University Intramural subject of "Application and Research of Micro Platform in Library Information Service" funded by (Project Number: XRW2014-18).

\section{Conflicts of Interest}

The author declares no conflicts of interest regarding the publication of this paper.

\section{References}

[1] Chinese Government Network (2018) Opinions of the CPC Central Committee and the State Council on Implementing the Strategy of Rural Revitalization. http://www.gov.cn/zhengce/2018-02/04/content_5263807.htm

[2] Bi, J. and Li, X.G. (2018) Research on the Role of University Libraries in the Context of Rural Revitalization Strategy. Rural Scientific Eriment, 8, 31.

[3] Feng, Y.C. (2016) Challenge and Innovation: Research on University Libraries' Cultural Poverty Alleviation. Library Work and Study, 9, 29-33.

[4] Zhao, Y.C. (2015) The Role of Local University Libraries in Prospering Local Rural Culture. Journal of Library and Information Science, 15, 61-63.

[5] Zhao, X.L. (2015) Research on the Countermeasures of University Library Serving the Cultural Construction of New Countryside. Office Operations, 7, 96.

[6] Chen, L.M. (2017) Research on Rural Culture Construction in Turpan Area under the Guidance of Modern Culture. Xinjiang University, Ürümqi. 